\title{
THE MECHANISM OF CELL BINDING AND GELL-SHEET FORMATION IN L STRAIN FIBROBLASTS ${ }^{1}$
}

\author{
R. J. KUCHLER, MARTHA L. MARLOWE and D. J. MERCHANT \\ Department of Microbiology of the William H. Singer Memorial Research Laboratory \\ of the Allegheny General Hospital, Pittsburgh, Penna., and Department of Bacteriology, \\ University of Michigan, U.S.A.
}

Received August 20, 1959

IN 1958 Merchant and Kahn [11] showed the formation of delicate membrane-like structures at the air-liquid interface in serum-free suspension cultures of L strain fibroblasts. These "cell sheets", when stained with hematoxylin and cosin or Masson's trichrome stain, gave a morphological picture suggestive of connective tissue. The sheets were composed of cells and fibers and electron microscopic observations indicated that these fibers contained proteins which had the characteristic structural patterns found in collagen fibers. Similar structures were reported by Pumper $[13]$ in stationary cultures of $\mathrm{L}$ strain and of mouse lung cells.

In the present paper results are presented showing that the fibrous protein is not necessarily a newly synthesized cell entity but may be present, to some extent, on the cell surface at all times; it is most likely the method of culturing that allows the protein to be bound to adjacent cells and to be drawn into strands as seen by microscopic examination. A probable mechanism is presented for fibroblast binding to glass and to other cells. The theory to be presented is consistent with that made by Leiberman and Ove [9] for fibroblasts of monkey kidney origin and adheres to postulations made by Danielli [2] concerning the nature of surface structures for metazoan cells.

\section{MATERIALS AND METHODS}

The cell strain used for this study was the $\mathrm{L}$ strain (929) mouse fibroblast isolated by Earle [3] from subcutaneous connective tissue of a normal C3H mouse and later cloned by Sanford et al. [14].

Replicate fluid suspension cultures were set up as described in a previous report [8]. In all experiments $80 \mathrm{ml}$ of a suspension containing approximately $2.5 \times 10^{5}$ to $3 \times 10^{5}$ cells $/ \mathrm{ml}$ in an appropriate medium was placed into each of several $250 \mathrm{ml}$ screw cap

\footnotetext{
${ }^{I}$ Supported by grants from the United Fund of Allegheny County and the U.S. Public Health Service (C-3720).
} 
Erlenmeyer flasks. Replicate cultures were harvested at various times throughout the growth cycle. Cultures were harvested in two $40 \mathrm{ml}$ conical centrifuge tubes by centrifuging at $600 \mathrm{~g}$ for 10 minutes. After centrifugation, the supernatant was removed as completely as possible and discarded. Five $\mathrm{ml}$ of $0.3 \mathrm{M}$ trichloroacetic acid (TCA) was added to the packed cell mass. This suspension was then heated at $90^{\circ} \mathrm{C}$ for 15 minutes to split the desoxyribonucleic acid (DNA) and ribonucleic acid (RNA) from tissue proteins. The insoluble residue was separated by centrifugation. The extracts from both tubes were combined and contained the DNA and total acid soluble RNA. The residues were combined and washed once with $5 \mathrm{ml} 0.3 \mathrm{M}$ TCA; this wash was added to the nucleic acid extract. The remaining residue was solubilized in $0.2 \mathrm{~N} \mathrm{NaOH}$. This fraction contained all of the cell protein which was not soluble in $0.3 M$ TCA. The TCA extract was analyzed for DNA by the Dische reaction and for RNA by the Mejbaum reaction [15]. Protein was determined in the alkali soluble fraction by the Folin method as modified by Lowry et al. [10].

The quantitative growth of fibroblasts in suspension cultures was analyzed by the above procedures in forr situations. In two cases cell sheets were formed and in the other two situations they were not formed. Since cell-sheet formation can be associated with the suspending medium in agitated suspension cultures, the four media are given as lollows:

Medium 1: Parker's 199 [12] with 0.5 per cent peptone ${ }^{1}$ (199 P) and 5 per cent whole horse serum; in this medium cells remained in suspension as discrete units.

Medium 2: Parker's 199 with 0.5 per cent peptone (199 P) and 0.12 per cent of 15 CPS methyl cellulose; it was observed in the course of the experiments that this compound could replace serum and maintain fibroblasts in suspension with growth comparable to that in serum.

Medium 3: Parker's 199 with 0.5 per cent peptone (199 P); in this medium cell sheets are formed rapidly and in large numbers [11]. These sheets usually measure between 0.5 and $2 \mathrm{~cm}$ in diameter.

Medium 4: Isotonic sodium chloride buffered with $0.005 M$ Tris at $\mathrm{pH} 7.5$; cell sheets formed.

In another series of experiments $0.1 \mathrm{M}$ sodium chloride was buffered with $0.05 \mathrm{M}$ phosphate at various $\mathrm{pH}$ values of 5.0-8.0. One-tenth molar sucrose was added to make the fluid slightly hypertonic. $L$ strain cells were added to these buffered solutions at a concentration of approximately $3 \times 10^{5}$ per $\mathrm{ml}$. Eighty $\mathrm{mI}$ of suspension was placed in each of several Erlenmeyer flasks in the same manner as for regular suspension cultures.

A cation exchange resin, Dowex $50 \mathrm{~W}-\mathrm{X} 8,200-400 \mathrm{mesh}^{3}$ was washed with $0.2 \mathrm{~N}$ $\mathrm{NaOH}$ to convert the resin to the sodium form. Resin particles of a size comparable to those of the fibroblast cells were separated by fractional sedimentation in a oneliter graduate cylinder. The larger particles sedimenting in fifteen minutes were not

1 Bacto-peptone, Difco Laboratories, Detroit, Michigan.

2 Dow Chemical Company, Midland, Michigan, Reagent Grade.

${ }^{3}$ Dow Chemical Company, Midland, Michigan. 
used. The supernatant containing the desired particles was separated. This suspension was shaken vigorously and resedimented. The procedure was repeated five times. The resin was then collected in a series of centrifuge tubes and the particles were washed several times with phosphate buffered saline at $\mathrm{pH}$ values of 5.0-8.0. Fibroblast cultures were set up in $0.1 M$ sodium chloride, $0.1 M$ sucrose, and $0.05 M$ phosphate buffer at a concentration of $2 \times 10^{5}$ cells $/ \mathrm{ml}$. An equal number of resin particles was added to the suspension in each Erlenmeyer flask and these were placed on the shaker.

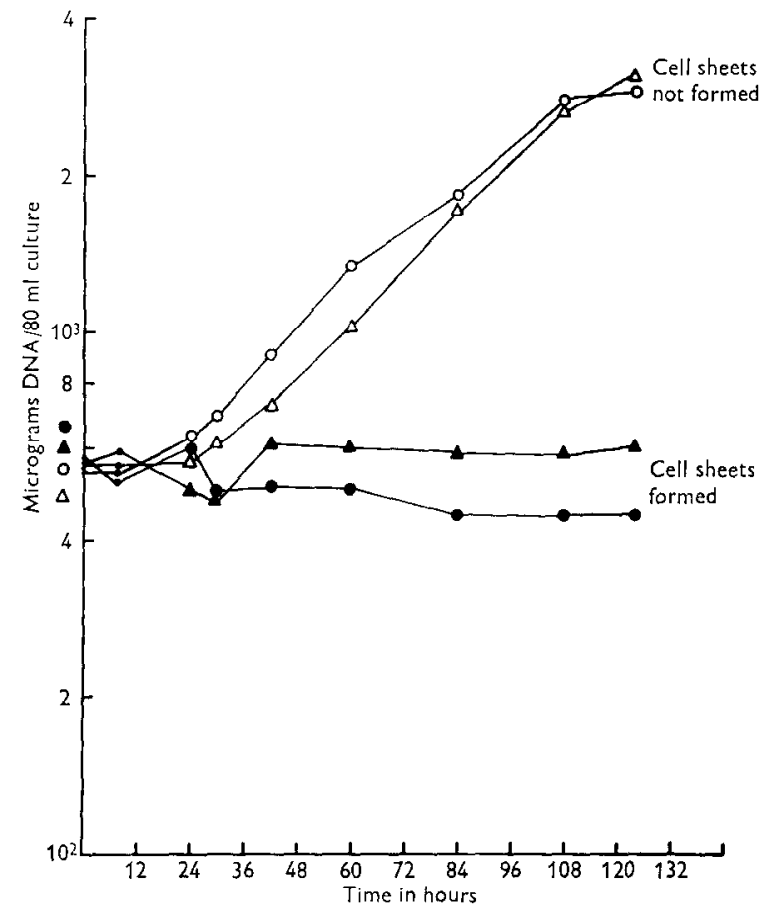

Fig. 1. - The synthesis of desoxyribonucleic acid by L strain fibroblasts in suspension cultures, comparing cultural situations, two where fibroblasts bind to each other forming cell-sheet structures, and two others where these same fibroblasts remain suspended as single rounded units. $\bigcirc-O, 199 \mathrm{P}_{85}+$ horse serum ${ }_{5} ; \Delta-\Delta, 199 \mathrm{P}_{97}+4$ per cent methyl cellulose $\mathrm{s}_{3} ; \Delta-\triangle, 199 \mathrm{P}_{100}$; $-\bullet, 0.85$ per cent $\mathrm{NaCl}$ buffered with $0.005 M$ tris $_{100}$.

\section{RESULTS}

Fig. 1 shows the synthesis of desoxyribonucleic acid studied under two conditions where cell sheets were formed and two situations where their formation did not occur. All of the cultures in these experiments were started with approximately $570 \pm 25 \mu \mathrm{g}$ DNA; it has been found that DNA correlates consistently with cell number in the L strain system [10]. This chart shows 
that growth occurs at a rapid rate in $199 \mathrm{P}$ supplemented with either a per cent horse scrum or 0.12 per cent methyl cellulose. This is consistent with the finding by Waymouth [16], that peptone supplements can support the growth of fibroblasts on a glass substrate in the absence of serum. Thus, we have shown that $199 \mathrm{P}$ supplemented with methyl cellulose serves as an excellent growth medium and sustained fibroblast growth in this medium has been obtained for over two years in suspension cultures. The growth is

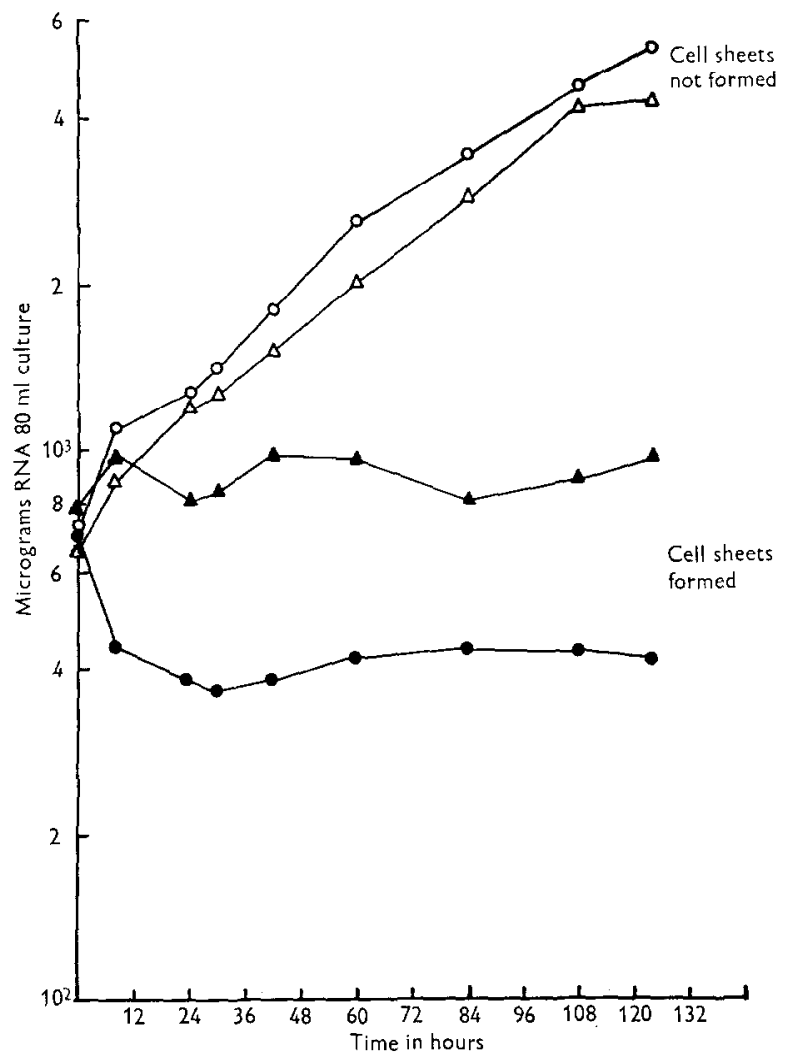

Fig. 2.- The synthesis of ribonucleic acid by $\mathrm{L}$ strain fibroblasts in suspension cultures, comparing cultural situations, two where fibroblasts bind to each other forming cell-sheet structures, and two others where these same fibroblasts remain suspended as single rounded units. $0-0,199$

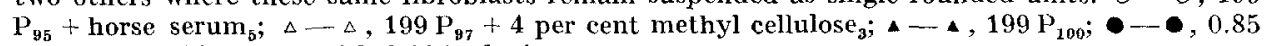
per cent NaCl buffered with $0.005 M$ tris $_{100}$.

even more satisfactory than that in media containing serum for purposes of cell studies since the cells disperse very well as single units, which facilitates counting and setting up replicate cultures. If serum or methyl cellulose is omitted from $199 \mathrm{P}$, however, cell-sheet formation occurs in suspension cul- 
tures and the net increase of DNA is shown to be minimal over the time period of the experiment. This occurs despite the fact that $199 \mathrm{P}$ is an adequate growth medium for these cells. The formation of cell sheets has also been observed in physiological saline buffered at $\mathrm{pH} 7.5$ as mentioned above. It is seen in Fig. 1 that there is no net increase in the content of DNA under

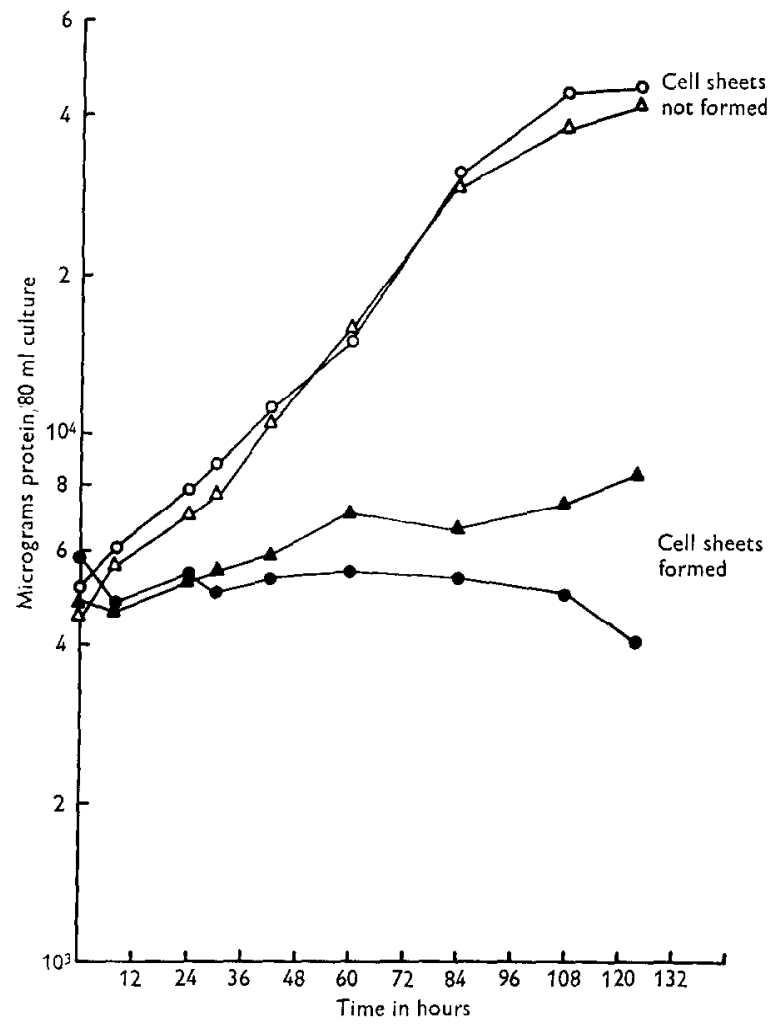

Fig. 3.-The synthesis of protein by $\mathrm{L}$ strain fibroblasts in suspensioin cultures, comparing cultural situations, two where fibroblasts bind to each other forming cell-sheet structures, and two others where these same fibroblasts remain suspended as single rounded units. $O-0199$ $\mathrm{P}_{95}+$ horse serum ${ }_{5} ; \Delta-\Delta, 199 \mathrm{P}_{97}+4$ per cent methyl cellulose $\mathrm{s}_{3} ; \triangleleft-\wedge, 199 \mathrm{P}_{100} ; \bullet-\bullet, 0.85$ per cent $\mathrm{NaCl}$ buffered with $0.005 M$ tris 100 .

these conditions though cell sheets are formed which appear to have the same characteristics as those previously described by Merchant and Kahn [11].

Results are presented in Fig. 2 of measurements of RNA synthesis under the same conditions of cell-sheet formation. It is interesting to note that synthesis of RNA in horse serum and methyl cellulose supplemented media are analogous. The situation in $199 \mathrm{P}$ and in sodium chloride where sheet 
formation occurs is slightly different. As long as a full complement of metabolites is present as in medium $199 \mathrm{P}$ then RNA does increase slightly, but RNA content actually decreases in saline. This may be accountable by leakage of ribonucleotides and ribonucleosides though cell integrity is apparently maintained since these cells will grow on transfer.

\section{TABLE I. "Cell-sheet formation" phosphate buffered saline $+0.1 \mathrm{M}$ sucrose after 15 minute incubation period.}

\begin{tabular}{cccc}
\hline pH 5.0 & pH 6.0 & pH 7.0 & pH 8.0 \\
\hline 0 & ++ & $+\div++$ & ++++ \\
\hline
\end{tabular}

Speculation was presented originally that a new protein might be synthesized in the form of a fiber $\lfloor 11\rfloor$. This has been re-examined and as shown in Fig. 3 there is no net increase in the content of protein in saline and yet cell sheets are formed. The formation of cell sheets is exceedingly rapid, occurring sometimes in 15 minutes or less. From this information it is assumed that protein is always present on the surfaces of these cells and when they are adjacent to each other in the absence of serum or methyl cellulose these proteins bind to each other and the physical agitation causes tension between the cells thus drawing out the fiber as a single contact between cells.

With the foregoing information available, the next logical question was concerned with the problem of how and why do these cells bind to each other in such a short period of time. If binding was mediated by a protein on the cell surface, then cell-sheet formation might be a function of $\mathrm{pH}$ because of the amphoteric nature of protein. Table I suggests that this was the case since the characteristics of the cell sheets varied in a series of separate cultures inoculated with single cell suspensions in buffered saline at $\mathrm{pH}$ values 5.0-8.0. The structural patterns of the sheets that formed at $\mathrm{pH} 7.0$ were the same as those observed in medium $199 \mathrm{P}$. In such cultures about 75 per cent of the cells were bound into sheets which floated freely on the surface, and the remaining single, rounded cells were dispersed in the underlying medium. This type of cell-sheet formation was designated as ++++ In cultures started at $\mathrm{pH} 8.0$ all of the cells in the culture became bound into a single sheet which covered the entire surface of the buffered solution in the Erlenmeyer flask; this was considered $\mathrm{a}++++$ cell sheet. In ++ sheet formation which occurred at $\mathrm{pH} 6.0$ approximately 50 per cent of the cells were contained in small sheets of about $0.5 \mathrm{~cm}$ diameter, and the remaining 
cells were dispersed in the medium. Cell-sheet formation did not occur at $\mathrm{pH} 5.0$.

Since it now appeared that we were concerned with binding between two proteins and binding was a function of $\mathrm{pH}$, we postulated that the amino acids concerned with binding should act as polar ions and should contain charged groups at $\mathrm{pH}$ values which are physiological for cell growth. From

TABLE II. Cell binding to cation exchange resin phosphate buffered saline $+0.1 \mathrm{M}$ sucrose after 15 minute incubation period.

\begin{tabular}{cccc}
\hline $\mathrm{pH} 5.0$ & $\mathrm{pH} 6.0$ & $\mathrm{pH} 7.0$ & $\mathrm{pH} 8.0$ \\
\hline 0 & ++ & $+1+1$ & $+1+++1$ \\
\hline
\end{tabular}

this it seemed likely that the carboxyl group was functional since it was consistent with binding mediated through polyvalent cations as a function of $\mathrm{pH}$. On the basic side of the isoelectric point of the protein the conjugate base would be present and the more basic the environment, the greater the number of free available groups to bind. This was consistent with our experiment and when the $\mathrm{pH}$ was high enough, about 8.5, all the cells clumped into one huge mass composed of cells and fibers.

To test further our hypothesis, an experiment was set up using a cation exchange resin. If binding occurred as we speculated, then the active ion exchange sites on the resin particles should act much like fibroblast combining groups. If the two were mixed in equal proportions, then a resin particle could bind a cell or another resin particle; likewise a cell could bind another cell or a resin particle This would be possible because polyvalent ions can replace sodium on the resin. Table II suggests that this was in effect the situation; macroscopically, the characteristics of the cell sheets were similar to those described in the previous experiment. Microscopic observations revealed resin particles randomly bound into cells sheets, and fibers from adjacent cells attached to the particles. Though we are not certain that the end group is a carboxyl group, it does seem logical since there are only a few choices in a protein.

\section{DISCUSSION}

Past evidence has indicated that a healthy, growing fibroblast in vitro will attach firmly to a suitable surface. However, recent work has shown that fibroblasts may also grow maximally in free suspension. In a previous report we showed that the $\mathrm{pH}$ for $\mathrm{L}$ strain fibroblast attachment is independent of 
the $\mathrm{pH}$ concerned with the maximum growth rate [7], and though these cells attach to glass readily at $\mathrm{pH} 7.5$ or above, and some of the capacity to attach is lost at lower $\mathrm{pH}$ values, the rate of growth appears maximal at about $\mathrm{pH}$ 7.0.

The mechanism of the attachment of cells to glass must be consistent with the fact that it can be reversed by trypsin or ethylenediamine tetraacetic acid. The tentative conclusion has been reached in the present study that a protein or protein-like derivative and also a cation that is at least divalent are involved in attachment. This suggests that cell to cell attachment is mediated by a mechanism analogous to cell attachment to glass as expressed by Lieberman and Ove [y]. The above mechanism of binding is consistent with the fact that $\mathrm{pH}$ values that are probably above the isoelectric point of the protein enbance hinding by increasing the negative charge of the molecule.

The fibrous protein(s) described by Merchant and Kahn [11] as having a periodic structure consistent with collagen is likely to be normally present on the surface of fibroblasts, growing in agitated or stationary cultures. Such fibrous entities have been demonstrated by electron microscopy to be present on the surface of red cells by Hillier and Hoffman [6]. They found an organization on red cell ghosts consisting of plaque-like molecules which they designated as lipid and fiber-like molecules which they considered to be proteins. Daniclli $[2\rfloor$ in his analysis of the chemical structure of the cell surface, conceives of it as composed of lipoid molecules with an adsorbed protein layer. He states that calcium is presumably bound to carboxyl groups of the proteins and phosphate groups of the lipoids. All the protein present on the surface of fibroblasts is probably not newly synthesized since the phenomenon of cell-sheet formation occurs in saline in as short a time period as 15 minutes when no net increase in protein, DNA and RNA is noted. These fibers then are likely the binding substances holding the fibroblasts together in the cell sheet.

Cells removed from a medium containing serum lose a portion of the bound serum proteins. This occurs because of simple dilution; the serumfree medium serves as an eluting agent reversing the equilibrium existing between serum protein, cell adsorption sites and adsorbed serum protein. Thus, in a serum-free environment the equilibrium shifts to make available free sites by dissociating the adsorbed protein. This then leaves free negative groupings or conjugate base structures at physiological $\mathrm{pH}$ levels. Positive ions then are attracted to these available sites and complexes which can be written (cation-cell site) ${ }^{+}$are formed. Undoubtedly there is an affinity for polycationic species as in cation exchange resin systems. The cell has a multitude of negative charges at physiological $\mathrm{pH}$ levels and in contact with 
a partially saturated environment of divalent cations such complexes will be attracted by other sites which have not as yet attracted a free cation, and may be written (cell site)- [17]. The cell sheets will form like a lattice and as the cultures are agitated, in the absence of serum or methylcellulose, binding occurs between adjacent fibroblasts and the tension resulting from agitation will expose the entire fiber.

Serum proteins then are bound to the surface of the cells in suspension cultures and stabilize them by providing a shell of protein around the cell. Methyl cellulose has been found capable of replacing horse serum in medium $199 \mathrm{P}$ so that the growth requirements are satisfied without need for serum proteins. Methyl cellulose used in these experiments contains some free carboxyl groupings ${ }^{1}$ and binding of methyl cellulose to the surface may occur in the same manner as that described for serum proteins. It has been further noted that the cells exist as more discrete units in methyl cellulose. This may be due to the presence of only a few free carboxyl groupings on the molecule and thus when all are bound the cell is stabilized in suspension as an almost neutral particle.

It is not clear at present whether the protein as it is present on the cell surface has a fibrous structure. Formation of collagen fibers from homogeneous solutions of rat tail tendon by physical manipulation is well known $[1,5]$.

\section{SUMMARY}

L strain mouse fibroblasts grow as single, rounded, independent units in suspension cultures containing horse serum. Serum is apparently not essential as a growth factor, since analogous and sustained growth can be obtained when methyl cellulose is substituted for serum in suspension culture. In the absence of either serum or methyl cellulose, binding occurs between adjacent cells and in suspension cultures cell sheets form. In this situation there is little or no net synthesis of DNA, RNA or protein. The protein involved in cell sheet formation is present on the surface of the cells at all times even when they are growing as rounded units in suspensions containing horse serum or methyl cellulose, since elaboration of fibers by such cells can be observed in a very short interval when they are transferred to saline. Binding between cells is dependent upon $\mathrm{pH}$ and these studies suggest that the phenomenon is due to cross linkage by polyvalent cations.

We wish to acknowledge the technical assistance of Miss Mary Lou Moore.

1 Personal communication from the Dow Chemical Company. 


\section{REFERENCES}

1. Bahr, G., Expll. Cell Research 1, 603 (1950).

2. Danielli, J. F., Cytology and Cell Physiology, pp. 152-157. G. Bourne (ed.), Glarendon Press, Oxford, 1951.

3. Earle, W. R., J. Natl. Cancer Inst. 3, 555 (1943).

4. Earle, W. R., Schilling, E. L., Bryant, J. C. and Evaxs, V. J., J. Natl. Cancer Inst. 14, 1159 (1954).

5. Gross, J., Highrekger, J. H. and Schmit, R. O., Proc. Soc. Expll. Biol. und Med. 79, 462 (1952).

6. Hillier, J. and Hoffmax, J. F., J. Cellular Comp. Physiol. 42, 203 (1953).

7. Kuchler, R. J. and Merchant, D. J., Proc. Soc. Exptl. Biol. and Med. 92, 803 (1956).

8. - Univ. Michigan Med. Bull. 24, 200 (1958).

9. Lieberman, I. and Ove, P., J. Biol. Chem. 233, 637 (1958).

10. Lowry, O. H., Rosebrough, N. J., Farr, A. L. and Randall, R. J., J. Biol. Chem. 193, 265 (1951).

11. Merchant, D. J. and Kahn, R. H., Proc. Soc. Expt. Biol. Med. 97, 359 (1958).

12. Morgan, J. F., Morton, H. J. and Parker, R. C., Proc. Soc. Exptl. Biol. Med. 73, 1 (1950).

13. Pumper, R. W., Proc. Soc. Exptl. Biol. Med. 99, 160 (1958).

14. Sanford, K. K., Eanle, W. R. and Likely, G. D., J. Natl. Cancer Inst. 9, 229 (1948).

15. Schneider, W. C., Methods in Enzymology. Vol. III, p. 680. S. P. Colowick and N. O. Kaplan (eds.), Academic Press, Inc., New York, 1957.

16. Waymouth, C., J. Nalt. Cancer Inst. 17, 315 (1956).

17. ZAGo, F., Thesis, Univ. of Michigan, 1956. 